\title{
The Republic of Bashkortostan as an experimental test site for the production of artificial hydrocarbons
}

\author{
Olga Fedorova ${ }^{1, *}$ \\ ${ }^{1}$ Ufa State Petroleum Technological University, 450064, Ufa, Russia
}

\begin{abstract}
The shifting of the oil extraction industry to the remote areas that are far from the regions with a developed petrochemical and oil refining industry implies high risks for the economic development of the latter. In the future, these enterprises may face risks of raw materials supply. So, some measures are needed to smooth out the spatial polarization of the territory in the future. For the transformation of the region's economy, it is proposed to present the Republic of Bashkortostan as an experimental test area for the artificial hydrocarbons production for the further production of an expanded range of commercial products, including composite propellant (mixed fuel). The potential participants of the experiment are discussed in the article. For example, Chishminsky Oil Extraction Plant, which recently produces rapeseed oil and exports to the countries of the European Union and China for the production of biodiesel. For the production of ethanol, it is also proposed to use the production facilities of "Bashspirt", located in the region. At the production site of such enterprises as the Branch of "Bashneft", it is possible to produce various nomenclature of commercial products based on oil in concentration with artificial hydrocarbons from vegtative raw materials.
\end{abstract}

\section{Introduction}

The economic situation in 2020 showed the intentions of the European oil and gas companies, in their strategic investment projects, in favor of the development of lowcarbon business lines. The low-carbon development involves the transformation of the economy, which covers such sectors as transport, agriculture, energy, construction and other sectors of the national economy. It is worth noting, that such companies as "Repsol", "Equinor", "BP", "Shell", "Total" announced the diversification of the production in favor of the "green" technologies. Thus, according to the data, which are provided [1], one of the main goals of "BP" is to increase the biofuel production from 22 thousand to more than 100 thousand barrels per day. These intentions may be caused by the striving to decrease the world oil prices, as well as to develop the "green" technologies in the sphere of artificial hydrocarbons, contributing to the reduction of the consumption of traditional oil. Whereas the Russian Federation is a major exporter of the non renewable energy resource - oil, its further export is impractical, as the costs of its search, development, extraction and transportation will remain high in the nearest future. At the same time, due to the shifting of the oil extraction industry to the remote areas that are far from the regions with developed petrochemical and oil refining industries, there are high risks of economic development of the latter. Hence, the problem of migration of the working people from these regions arises and leads to the deterioration in the quality of life and decrease in the number of people, living in these territories. The Republic of Bashkortostan is one of the examples of such development of events in the economy.

\section{Materials and Methods}

For the research of oil production and export on the territory of the Russian Federation, statistical data of the Ministry of Energy of the Russian Federation were used [2]. To analyze the production of the renewable energy resources based on biomass, statistical data from the International Energy Agency (www.iea.org) and the Department of Energy USA (www.energy.gov) were used. To find the scenario of the most optimal transformation of the territory's economy, taking into account the production and resource potential in the region, the models of economic researches, including the life cycle model of N. D. Kondratiev [3], the model of the intersectoral balance "output-costs" of V. V. Leontiev [4] were used. For the effective management of local collective resources, E. Ostrom's [5] theory of rational choice of collective action was used in the article.

\section{Results}

The analysis of statistical data [2] showed that oil production and export in the Russian Federation decreased in 2020 (Table 1.).

\footnotetext{
* Corresponding author: olgaf79@mail.ru
} 
Table 1. Analysis of oil production and export according to the data of the Ministry of Energy of the Russian Federation for the period of 2019-2020.

\begin{tabular}{|c|c|c|c|}
\hline $\begin{array}{c}\text { Oil } \\
\text { *(including } \\
\text { gas } \\
\text { condensate) }\end{array}$ & $\mathbf{2 0 1 9}$ & $\mathbf{2 0 2 0}$ & $\begin{array}{c}\text { coefficient of } \\
\text { change }\end{array}$ \\
\hline $\begin{array}{c}\text { Production*, } \\
\text { thousand tons }\end{array}$ & 560256.7 & 512761 & 0.92 \\
\hline $\begin{array}{c}\text { Export, } \\
\text { thousand tons }\end{array}$ & 266096.2 & 232371.6 & 0.87 \\
\hline
\end{tabular}

As it can be seen from Table 1, in 2020, oil production decreased by $8 \%$, export fell by $13 \%$. At the same time, the part of consumption in the domestic market is 52\% in 2019 and 54\% in 2020 . This dynamics indicates a slowdown in the oil production and export.

On the territory of the Republic of Bashkortostan there is a unique complex of the petrochemical and oil refining enterprises, which has been producing industrial and consumer goods for many decades. The total capacity of these production facilities is the largest in the Russian Federation [6]. Figure 1 shows the diagram developed on the basis of the socio-economic development strategy of the Republic of Bashkortostan until 2030 [7] based on the results of the shipped products volume in 2016. The main share of the industrial production is accounted for by the production of petroleum products, chemical production, and the extraction of fuel and energy resources, that indicates the dependence of the enterprises located on this territory on the volume of hydrocarbon production.

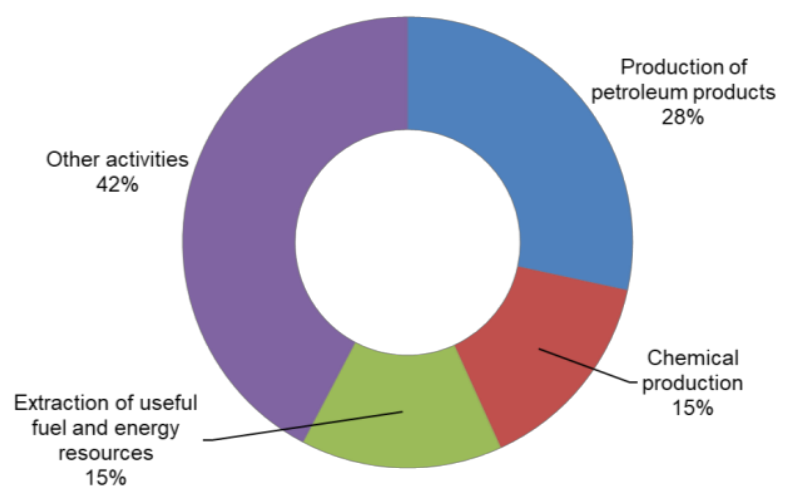

Fig. 1. The share of the industrial production in the Republic of Bashkortostan in 2016.

Thus, $58 \%$ of the industrial production in the region is accounted for by the type of business associated with the processing of a non - renewable energy resource oil. Due to the reduction of the recoverable oil reserves in the region and nearby territories [8], in Western Siberia [9], the polarization of this production in the Republic of Bashkortostan has high risks of further development.

At the same time, there is a high migration of the working population in the region $[10,11]$. To restrain the migration processes, it is necessary to provide employment, increase wages and improve the living standard and quality of life of the population on the territory. To achieve this goal, it is assumed to consider the Republic of Bashkortostan as an experimental test area for the artificial hydrocarbons production, which makes it possible to produce the innovative products, mixed fuel, for export to the European Union and China. Based on materials from the Department Energy USA (www.energy.gov) it can be stated that "mixed" fuel is the fuel derived from oil and alternative energy resources, for example, biofuels derived from vegetative raw materials.

Due to the fact that the production of diesel fuel and gasoline in the Republic of Bashkortostan is leading in all-Russian rating of regions for the production of the most important types of products in 2017-2019 [11], it is advisable to consider thoroughly the artificial hydrocarbons production to produce the biodiesel fuel, based on vegetable oils and bioethanol based on sugarcontaining crops. For the production of biodiesel the various oilseed crops are used, such as soy, sunflower, rapeseed, and so on. Vegetable oil is obtained by processing the seeds of oilseeds, after that the resulting liquid is refined and chemically treated. The biodiesel fuel obtained as a result of the further technological processing can be used as a part of various compositions with traditional oil fuel [12]. For the bioethanol production (ethyl alcohol), the sugar-containing crops such as sugar beet, corn, wheat and others are used.

Chishminsky Oil Extraction Plant LLC, which is the part of the Sigma's Companies Group, is actively operating in the region. In January 2021, at the production site of the Sigma's Companies Group Chishminsky Oil Extraction Plant LLC, the transition from the sunflower processing to the rapeseed processing was carried out. Rapeseed seeds were purchased from the enterprises of the agro-industrial complex of the region. The resulting rapeseed oil was shipped to China [13]. In the early periods of 2018, 2019, rapeseed oil was sent to European direction - to the Baltic plants, for the biodiesel production. Perhaps, the rapeseed oil was exported to Europe in 2020, too. Based on the information above, the plant, mentioned above may become a potential participant in the experiment. JSC "Bashspirt" can also become a potential participant in the experiment, as the largest producer of ethanol located in the region. According to thee results of the researches of the Department Energy USA (www.energy.gov) ethanol combined with gasoline increases the octane number, and the high octane number of the fuel compensates the fuel low energy density.

According to the research of the authors [14], which have shown the dependence of the effective specific fuel consumption and coefficient of efficiency from the crankshaft speed of the diesel engine and the additives of the rapeseed oil in the mixed fuel. As a result of the authors ' analysis of the calculated data for the diesel 4FFS 11.0/12.5 model D-245.5 C, the optimal proportion of the rapeseed oil in the mixed fuel is $50-70 \%$ of additive. At the same time the minimum effective specific fuel consumption and the maximum coefficient of efficiency are observed. Based on these data, it is 
possible to assume an increasing share of the biodiesel in the mixed fuel composition in the future.

It's necessary to take into account the fact that foreign manufacturers use diesel engines not only on trucks, special equipment and buses, but also expand their usage on passenger cars and low-tonnage vehicles. Thus, according to the work [1] and to "Perkis" data, 53\% of new French and $20 \%$ of new German cars are equipped with the diesel engines. According to "Peugeot" research, $62 \%$ of buyers in France and 29\% in Europe prefer a car with a diesel engine. The participants of the experiment can also become the production sites of such companies as branches of PJSC JSOC Bashneft: Bashneft-Ufaneftekhim, Bashneft-UNPZ, BashneftNovoil, which have the appropriate oil refining capacity in combination with the usage of artificial hydrocarbons from vegetable raw materials and are able to obtain an expanded range of commercial products, including mixed fuel.

At the same time, in the processing seeds of oilseeds, an expanded range of marketable products (cake, phosphatides, free fatty acids, wax, glycerin, etc.) are obtained and such products can be used in the different production sectors of the consumer goods.

Therefore, the integration of the enterprises and organizations into a cluster $[15,16]$ will contribute to better coordination of the industrial policy of petrochemical, oil refining industries and the enterprises of the agro-industrial complex. The cluster will also contribute to slowing down migration processes in the region, providing new jobs, including rural areas, developing agglomerations of territories, and transforming the region's economy.

\section{Discussion}

The development of the production of renewable energy resources will allow to reduce the consumption of nonrenewable energy resources - hydrocarbons. According to the research data of the International Energy Agency (IEA) (www.iea.org) materials, the actual for 2013-2018 and predicted for 2019-2024 scenario of biodiesel production by major countries is presented.

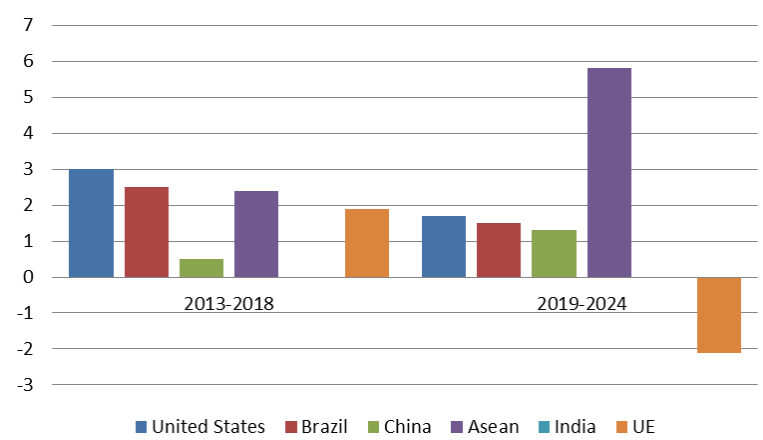

Fig. 2. The actual and predicted scenario of biodiesel production by major producing countries, billion liters.

As we can see from Figure 2, Asian countries will increase their production of biodiesel in the nearest future, while EU countries will reduce its production and start importing it.

Based on the materials of the International Energy Agency (www.iea.org), Figure 3 shows the actual production of ethanol for the period of 2013 -2018 and the predicted scenario for the period of 2019-2024 for the main producing countries.

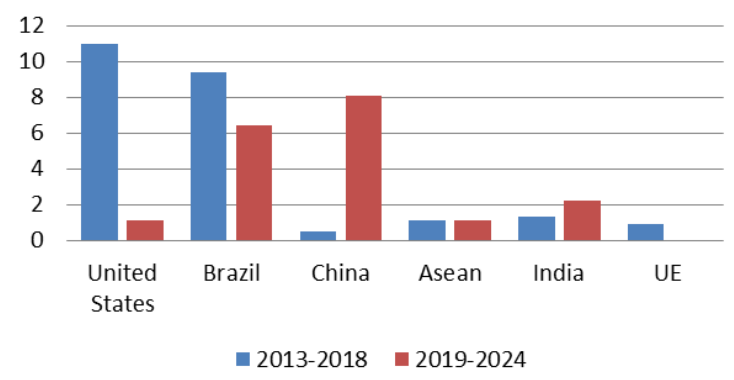

Fig. 3. The actual and predicted scenario of the ethanol production for the main producing countries, billion tons.

As it can be seen from Figure 3 in the short-term perspective China and India will increase their ethyl alcohol production.

As demand creates supply, obviously, the proposal for the production of mixed fuel-biodiesel and bioethanol in Republic of Bashkortostan with the aim of exporting it, is relevant.

\section{Conclusion}

According to the above mentioned data, in our opinion, there is a necessity to create an experimental test area for the artificial hydrocarbons production. The territory of the Republic of Bashkortostan, which can stimulate the transformation of the region's economy, can become such an experimental test site.

I would like to express my special gratitude to the pedagogical staff of the FSBEI HE Ufa State Petroleum Technical University for their relevant comments and recommendations.

\section{References}

1. N.A. Ivanov, Modern problems of the national economy: a collection of works of the All-Russian scientific video conference of students, graduate students and young scientists (Ufa, Publishing house of USPTU, 2020)

2. Statistics [Electronic resource], Ministry of Energy of the Russian Federation (2020) Available https://minenergo.gov.ru/activity/statistic (accessed: 20.08.2020)

3. N.D. Kondratyev, World economy and its conjuncture during and after the war (Vologda, Regional branch of the State Publishing House, 1922)

4. W. Leontief, Weltwirtschaftliches Archiv, 2, 22 (1925) 
5. E.A. Ostrom, Political Sc. R., 1 (1998)

6. Register of designed, built and put into operation oil refineries in the Russian Federation [Electronic resource], Ministry of Energy of the Russian Federation Available at: https://minenergo.gov.ru/opendata/7705 847529-reestrnpz (accessed: 05.08.2020)

7. Strategy of socio-economic development of the Republic of Bashkortostan for the period up to 2030 [Electronic resource], Ministry of Economic Development and Investment Policy of the Republic of Bashkortostan Available at: https://economy.bashkortostan.ru/documents/acti ve/298367/ (accessed: 10.08.2020)

8. Chronicle of Bashkir oil (Ufa, Bashgeoproekt, 2007)

9. V.M. Tarasyuk, Solution of organizational and economic problems of increasing oil recovery from Siberian production fields (Moscow, Chemistry, 2001)

10. O. Fedorova, Sh. Valiev, N. Sukhankina, E3S Web of Conferences, 222 (2020)

11. Statistical reference book of the Republic of Bashkortostan 2017-2019 [Electronic resource], Bashstat Available at: https://bashstat.gks.ru/storage/mediabank (accessed: 20.08.2020)

12. A.A. Ivanov, Assessment of the performance of the machine-tractor unit when working on methanol-rapeseed emulsion, FSBEI HE "Tver State Agricultural Academy" (2017)

13. State Corporation "Sigma" begins shipping rapeseed oil in flexi-tanks [Electronic resource], State Corporation "Sigma" Available at: https://tdsigma.ru/news/4795 (accessed: 02.02.2020)

14. Sh.V. Buzikov, S.A. Plotnikov, I.S. Kozlov, J. V. Tr. Pov., 5 (2020)

15. Sh.Z. Valiev, N.V. Isaeva, O.A. Fedorova, J. V. UGNTU, 1 (2018)

16. Sh.Z. Valiev, O.A. Fedorova, J. V. UGNTU, 4 (2019). 